Z. Kélin. Chenr. Klin. Biochem.

10. Jg. 1972 , S. $562-565$

\title{
Definitions of Human Bilirubin and Bilirubin Compounds
}

\author{
By J. Fog and A. F. BAKKeN \\ Pediatric Research Institute, University of Oslo, Rikshospitalet, Oslo, Norway
}

(Eingegangen am 15. Mai/14. August 1972)

A proposal is made for the chemical, physical and clinical definitions of human bilirubin and bilirubin compounds. The necessity for A proposal is made for the chemical, physical and clinical definitions of human befing Federation of Clinical Chemistry) when, in 1970, it elected an expert panel on bilirubin. No proposals have so far been made by this panel.

New findings published and presented during the last few years make it still more needful to give a gencral review of the problems connected to bilirubin nomenclature.

Es wird ein Vorschlag für die chemische, physikalische und klinische Definition von menschlichem Bilirubin und Bilirubin-Verbindungen gemacht. Die Notwendigkeit neuer Definitionen wurde in den Diskussionen auf internationalen Bilirubin-Tagungen betont. Dies wurde gemacht. Die Notwendigkeit neuer Definitionen wurca in Bisher hat diese Kommission keine Vorschläge gemacht. Die in den letzten Jahren veröffentlichten und vorgetragenen neuen Ergebnisse machen es noch erforderlicher, einc generelle Ubbersicht über die Probleme, die mit der Bilirubin-Nomenklatur verbunden sind, zu geben.

Bilirubin is formed in humans, as far as it is known. today, as a degradation product of protoporphyrin. Hemoglobin, which is the most abundant source for bilirubin production, contains ferroprotoporphyrin IX (one of the 15 possible isomers of protoporphyrin). It has been proved that, in vivo, this porphyrin is cleaved at the $\alpha$-bridge only, resulting in a bilirubin IX (1). It is doubtful that this is the only isomer of bilirubin formed in vivo, because the III $\alpha$ and XIII $\alpha$ isomers have been isolated from commercial bilirubin prepared from natural sources. Bilirubins from other porphyrins have, so far, not been identified.

It must be emphasized that chemically pure bilirubin in the crystalline state and bilirubin bonded to proteins, lipids and membrane structures in the dynamic state of the living cell may behave quite differentely, and that tautomeric forms and steric structures of bilirubin which are present even in trace amounts only, in pure preparations, may be the dominating structures in vivo. This could explain the many difficulties in handling bilirubin and bilirubin compounds when they are present in biological materials.

\section{Chemically "pure" Bilirubins}

McDonagh and Assrs (2) discovered that three bilirubin isomers were present in some commercial preparations of bilirubin. One of the commercial preparations supposed to be especially pure (3) contained $16 \% \operatorname{III} \alpha$, $22 \%$ XIII $\alpha$ and only $62 \%$ of bilirubin IX $\alpha$. Isomers were not found if bilirubin IX $\alpha$ was treated with alkaline solution, while acid treatment immediately gave the theoretical yield of $25 \% \mathrm{III} \alpha, 50 \%$ IX $\alpha$ and $25 \% \mathrm{XIII} \alpha$ isomers with a transitory cleavage of the central methylene bridge and a random reunion of the dipyrrols (4). After an hour the $\mathrm{XIII} \alpha$ isomer dominated. Isomeriza- tion of porphyrinogens in hot acid is also well known (5). Whether the bilirubin IX $\alpha$ is the only bilirubin in vivo and the other isomers are products of purification only, is not yet clear.

It is surely the multiplicity of degrading pathways which decide the fate of different porphyrins. The end product can be bilirubin IX $\alpha$ as from protoporphyrin IX, dipyrrols, or probably even still simpler compounds.

Tab. 1

Bilirubin (in lactam from) and its isomers

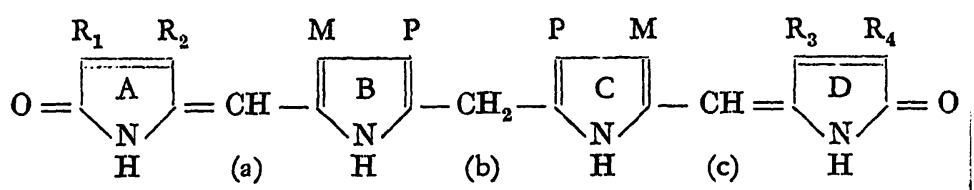

$\mathrm{M}:-\mathrm{CH}_{3}$ (methyl)

$\mathrm{V}:-\mathrm{CH}=\mathrm{CH}_{3}$ (vinyl)

P: $-\mathrm{CH}_{2}-\mathrm{CH}_{2}-\mathrm{COOH}$ (propionic acid)

\begin{tabular}{lcccccc}
\hline Isomers (1) & $\mathrm{R}_{1}$ & $\mathrm{R}_{2}$ & $\mathrm{R}_{3}$ & $\mathrm{R}_{4}$ & $\left.\varepsilon_{\max }{ }^{1}\right)$ & $\begin{array}{c}\lambda_{\max } \text { Ab- } \\
\text { sorption } \\
{[\mathrm{nm}]}\end{array}$ \\
\hline III $\alpha$ & $\mathrm{V}$ & $\mathrm{M}$ & $\mathrm{M}$ & $\mathrm{V}$ & 65200 & $455-458$ \\
IX $\alpha$ & $\mathrm{M}$ & $\mathrm{V}$ & $\mathrm{M}$ & $\mathrm{V}$ & 62600 & $453-455$ \\
XIII $\alpha$ & $\mathrm{M}$ & $\mathrm{V}$ & $\mathrm{V}$ & $\mathrm{M}$ & 52500 & $449-453$ \\
\hline
\end{tabular}

1) In chloroform.

Bilirubin may exist in several tautomeric forms: 1 . Electrons $(\pi)$ can move intramolecularly within the two halves of the molecule because of the unbroken row of conjugated double bonds. Electrons can thereby be dislocated from a vinyl (on ring $A$ or $D$ ) to the middle bridge (b) resulting in a dihydrobiliverdin (6).

2. The pyrrol-rings $A$ and $D$ can exist either in lactam or in lactim forms (7). 
3. Intramolecular hydrogen bonds can exist between one or both of the two carboxyl groups and pyrrol-N $(8,9$, $10)$ or between the two carboxyl groups.

4. It was proposed (11) that the vinyl on ring $D$ forms a furan ring with a lactim hydroxyl on ring $D$, and although this has been disproved in vitro (12), it may still occur in vivo.

5. With the pyrrol rings $A$ and $D$ or $D$ and $A$, respective$\mathrm{ly}$, in lactam and lactim form, the whole molecule may condense into a ring-structure kept together by hydrogen bindings (ring $\mathrm{A}-\mathrm{O}-\mathrm{H}-\mathrm{O}$-ring $\mathrm{D})(13,14,15,16)$. 6. Numerous steric structures are possible, and the structure present in a certain situation depends on the neighbouring molecules.

\section{Bilirubin in Biology}

We know nothing about the tautomeric form or forms of bilirubin present in biological fluids. In particular, we know nothing about the bilirubin molecule when it is linked to the specific site on the microsomal enzyme. Physical and chemical conditions affecting esterification of bilirubin may just as well influence the equilibrium between different forms of bilirubin as the enzyme itself.

Bilirubin and bilirubin-compounds as they are found in man can be classified either according to their peculiar qualities or to their localisation. A chemical, a physical and a clinical classification are necessary to cover the whole biological field of bilirubin in humans. It is still too early to classify bilirubins as to their origin corresponding to pathohem, heme, heme a and heme $a_{2}$ (17).

A chemical classification is necessary to give exact names to properly identified compounds. A physical classification is important because the different compounds have to be fractioned and purified by physical methods. Clinically, the important points are the synthesis, transportation, accumulation, toxicity, and excretion of the different compounds.

\section{Chemical classifications}

Bilirubin (earlier called unconjugated bilirubin)

1. Bilirubin-proteins

a) bilirubin-albumin

b) bilirubin-specific liver proteins $(Y \& Z)$. (18)

c) bilirubin-other proteins including enzyme-bonded bilirubin

2. Bilirubin-phospholipid-albumin $(12 ; 19,21,22)$.

3. "Free" bilirubin (not protein-bonded) (22).

4. Bilirubin-metal-complexes $(24,25)$.

Bilirubin-esters (earlier called conjugated bilirubin)

1. Bilirubin mono- or di-esters

a) with glucose $(\beta$-glucoside) $(26,27)$

b) with glucuronic acid ( $\beta$-glucuronide) $(28,29,30,31)$ c) with xylose ( $\beta$-xyloside) (26)

d) with disaccharides ( $\beta$-disaccharide) (32)

2. Bilirubinesters-phospholipid-albumin (32).

The terms conjugated and unconjugated bilirubin should be avoided, both because these words are used for so many different compounds (ethers, glucuronic acid linked to nitrogen in aromatic compounds), and because the word conjugated is used for other purposes in organic chemistry. With bilirubin, only esters have been identified to date. Seen from the bilirubin molecule the link is an ester, therefore, bilirubin ester, while the compound seen from the sugar side is a "glucoside". The esters. with glucuronic acid and xylose, for instance, are therefore called bilirubin glucuronide and bilirubin xyloside.

Bilirubin seems to be bonded to a specific site on the albumin molecule. One molecule of albumin binds one molecule of bilirubin very tightly and a second molecule more loosely (34). The specific liver cell proteins ( $Y \& Z$ ) are supposed to represent intracellular transport proteins for bilirubin (18). This is still disputed because of unfavorable equilibrium constants for the bilirubinalbumin bond. However, experiments done in vitro tell very little about how the bilirubin-protein bonds behave within the living liver cell.

Both bilirubin and bilirubin esters form complexes with phospholipids. They are extractable from serum with diethylether and are usually called ether-soluble bilirubin (35). The link between bilirubin and the phospholipid is usually broken by ethanol (20).

"Free" bilirubin is a fraction of serum bilirubin which under certain circumstances is oxidized to biliverdin by peroxidase, while bilirubin bonded to albumin is resistant to this treatment (23). However, this "free" bilirubin may be bonded to peptides, amino acids or other small molecules present in serum and, therefore, it is for the moment reasonable to call this fraction: nonprotein-bonded bilirubin. Bilirubin-aminoacid complexes, for instance, can be formed in vitro (36).

Bilirubin-metal complexes have been made in vitro (24, 25) and there are no reasons not to believe that such complexes can.also exist in vivo, especially since bilirubin can take on a ring-like configuration with one of the end pyrrol-rings in a lactim form and the other in a lactam form (see above).

The question of the existence of monoesters of bilirubin (37) has been under discussion for a long time. Their probable existence has now been settled by chromatographic studies of amides formed from bilirubin esters (38). It is assumed on the basis of considerable evidence that two forms of "monoesters" can be present, one a complex of bilirubin and bilirubindiester, and the other a true monoester (39).

Bilirubin esters with glucose and xylose have been identified in dog bile $(40,41)$ and also in human bile (42). These esters are formed by liver homogenates in the presence of UDP-glucose or UDP-xylose $(27,42)$. That 
glucosides and xylosides are formed together with the glucuronide is reasonable due to the scheme:

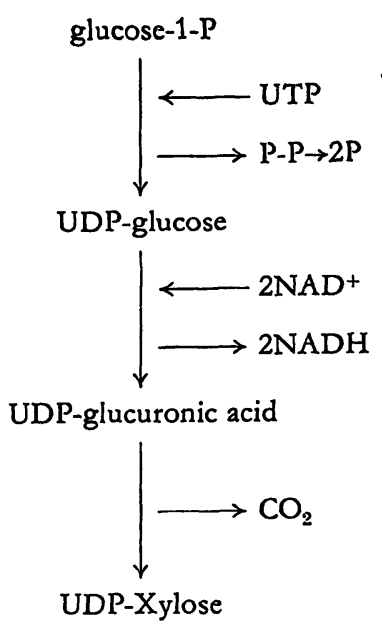

It is important for bilirubin esterification that UDPglucuronic acid is a relatively weak competitor of UDPglucose while the inhibition by UDP-xylose is much more pronounced (42).

However, it is astonishing that, up to date, esters with galactose have not been found in spite of the close relation of : UDP-galactose to UDP-glucose. Trace amounts of bilirubin-galactoside is formed by rat liver homogenates (27).

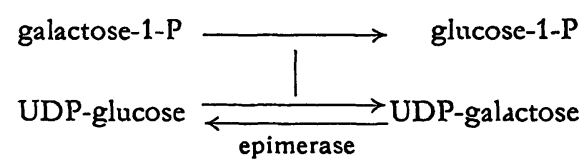

The esters with disaccharides isolated and described by KüNZLE (32) are probably products formed by the numerous glucosidases and glucosidetransferases present in the liver cell which can add another monosaccharide to the glucuronic acid on bilirubin glucuronide or to glucose on the glucoside.

Nothing is known of the significance of these different esters, all identified by different azo-pigment-techniques. Esters with the monosugars have also been found in the bile from rats and a number of other animals (42). Even when the bile ducts in rats are occluded for a short time there is a shift in the relative amounts of the various bilirubin esters in the bile (45).

Physical classification

\section{Hydropbile bilirubins}

1. bilirubin-protein complexes

2. bilirubin esters

3. "free" bilirubin

4. bilirubin ionized or dissolved with either complexing agents or substances opening hydrogen bondings.

\section{Hydrophobe bilirubins}

1. bilirubin

a) with intramolecular hydrogen bonds (intramolecular complexes).

b) with intermolecular hydrogen bonds (intermolecular complexes).
2. bilirubin-phospholipid complexes

a) with bilirubin

b) with bilirubin esters

It is of utmost importance to have bilirubins classified according to their hydrophile or hydrophobe nature, and in the future it will be desirable to have still more exact values for these qualities than the chromatographical behaviour and $R_{\mathrm{F}}$-values of their azo-pigments.

The distribution of bilirubin between water and chloroform depends, for instance, on the carboxyl on the propionyl groups. If the are ionized, bilirubin is almost totally transferred into the water phase, while nonionized bilirubin-carboxyl groups are "hidden" by intramolecular hydrogen bonds, as described above, so non-ionized bilirubin is almost completely extracted into the chloroform.

With increasing concentration, bilirubin has a tendency to polymerize, both in hydrophilic and hydrophobic solutions $(14,46)$.

\section{Clinical classification}

Icterus due to bilirubin, only

1. Premicrosomal

a) prehepatic as with hemolytic icterus

b) intrahepatic due to transport inhibition or defect as with flavispidic acid (17)

2. Microsomal

a) intrahepatic as with enzyme inhibition or defect $2 s$ in GILBERT's disease.

\section{Icterus due to bilirubin esters and bilirubin}

\section{Postmicrosomal}

a) intrahepatic

a) excretory inhibition or defect as in Dubin-Johinson disease.

$\beta$ ) intrahepatic cholestasis as with chlorpromazin

b) posthepatic

a) extrahepatic cholestasis

It is reasonable to link a clinical classification to the microsomes (47) instead of the liver cell, because esterification takes place in the microsomes, and because defects have been detected both in the intracellular transport and excretion of bilirubin from the liver. Clinically, it is possible to determine whether bilinubin only, or bilirubin esters (postmicrosomal) and bilirubin are present in serum. Traditionally, it is assumed that the urine contains only bilirubin esters.

Reasonably reliable methods for the quantitative fractionation of serum bilirubin esters and bilirubin have yet to be published. The difficulties are that the high protein content in serum makes extraction procedures difficult without ruining the ester bond, that bilirubin and especially bilirubin esters are easily oxidized to biliverdins, that bilirubin and bilirubin esters behave in the same way when they are linked to phospholipids, and that isomerization around the middle bridge (b) in the bilirubin molecule must be avoided. 
In the future it is reasonable to anticipate that bilirubin and bilirubin esters can be fractionated also from the serum and urine. Then, it may be possible to show, as it is anticipated, that the occlusive sequence of bilirubin and bilirubin esters in serum is: bilirubin, bilirubin mono-esters, bilirubin diesters, bilirubin esterified by disaccharides, and then at last a cleavage (39) of the ester bond with another increase in bilirubin.

It seems today difficult to have any idea about the normal or pathological proportions of different bilirubins in human bile, serum or urine and the significance of quantitative fractionations.

\section{References}

1. Gray, C. H., Nicholson, D. C. \& Nicolaus, R. A. (1958), Nature (London) 181, 181-183. - 2. MCDonAGH, A. F. \& Assis, F. (1971), FEBS Lett. 18, 315-317. - 3. Schellong, G. (1962), Ikterus Neonatorum, p. 51, Thieme Verlag, Stuttgart. 4. McDonagh, A. F. \& Assis, F. (1972), in press. - 5. Mauzerall, D. (1960), J. Amer. Chem. Soc. 82, 2601-2605. - 6. GrAY, C. H., Kurczycka, A. \& Nicholson, D. C. (1961), J. Chem. Soc. 2268-2275. - 7. GrAY, C. H. (1961), in Bile Pigments in health and Disease, p. 6, C. C. Thomas Publ., Springfield. - 8. FoG, J. \& JeLLUM, E. (1963), Nature (London) 198, 88-89. - 9. BRODERSEN, R., FloodgaArd, H. \& Krogh-Hansen, J. (1967), Acta Chem. Scand. 21, 2284-2285. - 10. Hutchinson, D. W., Johnson, B. \& KNELL, A. J. (1971), Biochem. J. 123, 483-484. 11. Fischer, H. \& HaberLand, H. W. (1935), Hoppe-Seyler's Z. Physiol. Chem. 232, 236-258. - 12 Fischer, H. \& PlieNINGER, H. (1942), Hoppe-Seyler's Z. Physiol. Chem. 274, 231-260. - 13. Fog, J. \& Bugge-Asperhenr, B. (1964), Nature (London) 203, 756-757. - 14. FoG, J. (1967), in BOUCHIER, I. A. D. \& Brling, B. H., Bilirubin Metabolism, p. 142, Blackwell Publ., Oxford. - 15. Gray, C. H., KulCZYCKa, A. \& Nicholson, D. C. (1961), J. Chem. Soc. 2276-2285. - 16. Lemberg, R. \& Legge, J. W. (1949), Hematin Compounds and Bile Pigments, p. 118, Interscience Publ., New York. - 17. FALK, J. E. (1963), in Comprehensive Biochemistry (Frorkin, Mc. \& Stotz, E. H. ed.), Vol. 9, p. 16, Elsevier Publ., Amsterdam. 18. Levi, A. J., Gatmartan, Z. \& Ariaș, I. M. (1968), J. Clin. Invest. 47, 61A. - 19. Howe, R. B. \& DE PiNTo, S. T. (1966), Medicine 45, 523-528. - 20. Talafant, E. \& Appelt, G. in 1. c. (14) p. 103-105. - 21. Howe, R. B. (1968), in Ikterus (BECK, K. ed.) p. 79-84, Schattauer Verlag, Stuttgart. - 22. Talafant, E., in 1. c. (21) p. 84-85. - 23. Jacobson, J. \& Fedpers, O. (1970), Scand. J. Clin. Lab. Invest. 26, 237-241. -
24. Velapoldi, R. A. \& Menis, O. (1971), Clin. Chem. 17, 1165-1170. - 25. Murakam, Y., Matsuda, Y. \& KanaOKa, Y. (1971), Bull. Chem. Soc. Jap. 44, 409-415. - 26. Fevery, J., van Hees, G. P., Leroy, P., Compernolle, F. \& Heirwegh, K. P. M. (1971), Biochem. J. 125, 803-810. - 27. Wong, K. P. (1971), Biochem. J. 125, 929-934. - 28. BILliNG, B. H. \& LATHE, G. H. (1956), Biochem. J. 63, 6 p. - 29. Schmidt, R. (1956), Science 124, 76-77. - 30. Scrimrd, R. (1956), Schweiz Med. Wochenschr. 86, 775-776. - 31. Talafant, E. (1956), Nature (London) 178, 312. - 32. KüNZLE, C. C. (1970), Biochem. J. $119,411-435$. - 33. Beck, K. in 1. c. (20) p. 85-91. - 34. Bratlid, D. \& Fog, J. (1970), Scand. J. Clin. Lab. Invest. 25, 257-261. - 35. Varela-Fuentes, B. \& Viana, C. (1933), C. R. Soc. Biol. 114, 789-792. - 36. Küster, W. (1924), HoppeSeyler's Z. Physiol. Chem. 141, 40-54. - 37. Billing, B. H., Cole, P. G. \& LAThe, G. H. (1957), Bioch=m. J 65, 774-784. 38. Brling, B. H. \& Jansen, F. H. (1971), European Association for the study of the liver-mceting. - 39. Ostrow, J. D. \& MURPHY, N. H. (1970), Biochem. J. 120, 311-327. - 40. HeIRWEGH, K. P. M., van Hess, G. P., Compernolle, F. \& Fevery, J. (1970), Biochem. J. 120, 17 p. - 41. Fevery, J., van Hees, G. P., ComperNOLLE, F. \& HeIrWeGH, K. P. M. (1971), Biochem. J. 125, 803-810. - 42. Fevery, J., Compernolle, F. \& de Groote, J. (1971), European Association for the study of the liver-meeting. 43. BILliNG, B. H. (1971), personal communication. - 44. Molz, R. J. \& Zanishefsky, I. (1971), Biochim. Biophys. Acta 250, 6-13. - 45. Van Damme, B., Fevery, J. \& Heirwegh, K. P. M. (1971), Experientia 26, 27-28. - 46. Brodersen, R. (1966), Acta Chem. Scand. 20, 2895-2896. - 47. Fevery, J., Claes, J., Heirwegh, K. P. M. \& de Groote, J. (1967), Clin. Chim. Acta $17,73-79$.
Dr. med. Arne Bakken Pediatric Research Inst. University of Oslo Rikshospitalet Oslo 1

Norway 